\title{
RADIATION EXPOSURE DURING SPINE SURGERY USING C-ARM FLUOROSCOPY
} EXPOSIÇAO A RADIAÇÃO DURANTE CIRURGIAS DE COLUNA
COM RADISOCOPIA

\author{
Alexandre Fogaça CRistante ${ }^{1}$, Fábıo Barbierl ${ }^{2}$, Almy Anacleto Rodrigues da Silva ${ }^{2,3}$, José Claudio Dellamano 4,5 \\ 1. Universidade de São Paulo, Faculdade de Medicina, Hospital das Clínicas (IOT-HCFMUSP), Instituto de Ortopedia e Traumatologia, Spine Surgery Division, Laboratory of Medical \\ Investigation, São Paulo, SP, Brazil. \\ 2. Universidade de São Paulo, Faculdade de Medicina, Hospital das Clínicas (IOT-HCFMUSP), São Paulo, SP, Brazil. \\ 3. Instituto Paulista de Dosimetria das Radiações, São Paulo, SP, Brazil. \\ 4. Centro Universitário SantAnna, São Paulo, SP, Brazil. \\ 5. Instituto de Pesquisas Energéticas e Nucleares (IPEN), São Paulo, SP, Brazil.
}

\section{ABSTRACT}

Objective: To evaluate the radiation dose received by staff in spine surgeries, including those who are not considered occupationally exposed workers. Methods: All spinal surgeries performed in the same department during a period of 12 months were evaluated with regard to the exposure of surgeons, scrub nurses, and auxiliary personnel working in the operating room to radiation from C-arm fluoroscopy. Radiation was measured by 15 film badge dosimeters placed on the professionals' lapels, gloves, and room standardized sites. The films were analyzed in the dosimetry laboratory by collections per period. Results: During the 12 months, 81 spinal surgeries were performed by the same team, with surgical times ranging from 1 to 6 hours. The total radiation dose ranged from $0.16 \mathrm{mSv}$ to $2.29 \mathrm{mSv}$ depending on the dosimetry site. The most exposed site was the wrist of the main surgeon. Conclusion: The results showed that in the spinal surgeries in our setting, the radiation doses are low and within legal limits. Nevertheless, constant training of professionals is essential for radiation protection of medical staff and patients. Level of evidence I/b, exploratory cohort study.

Keywords: Radiation. Absorption, Radiation. Radiation, lonizing. Radiation Exposure. Radiation Dosage. Radiography.

\section{RESUMO}

Objetivo: Avaliar a dose de radiação recebida pela equipe cirúrgica em cirurgias de coluna, incluindo entre aqueles que não são considerados trabalhadores com exposição ocupacional. Método: Todas as cirurgias de coluna realizadas num mesmo departamento num período de 12 meses foram avaliadas quanto à exposição dos cirurgiões, enfermeiros/instrumentadores e auxiliares trabalhando na sala cirúrgica à radiação do fluoroscópio tipo "C-arm". A radiação foi medida por 15 dosímetros de filme posicionados nas lapelas, luvas dos profissionais e também em pontos padronizados da sala. Os filmes foram analisados no laboratório de dosimetria em coleções por período. Resultados: Durante 12 meses, 81 cirurgias de coluna foram realizadas pela mesma equipe, e cada cirurgia durou entre 1 e 6 horas. A dose total de radiação variou de 0,16 mSva 2,29 mSv dependendo do local de mensuração. O local com maior exposição foi o punho do cirurgião principal. Conclusão: Os resultados mostraram que nas cirurgias de coluna no nosso serviço, as doses de radiação foram baixas e dentro dos limites legais. Porém, o treinamento dos profissionais é essencial para a proteção contra a radiação dos profissionais de saúde e seus pacientes. Nível de evidência I/b, estudo de coorte exploratório.

Descritores: Radiação. Absorção de radiação. Radiação ionizante. Exposição à radiação. Dose de radiação. Raios $X$.

Citation: Cristante AF, Barbieri F, Silva AAR, Dellamano JC. Radiation exposure during spine surgery using c-arm fluoroscopy. Acta Ortop Bras. [online]. 2019;27(1):46-9. Available from URL: http://www.scielo.br/aob.

\section{INTRODUCTION}

Since Wilhelm Röntgen discovered x-rays in 1895, medicine has been using its benefits for diagnoses and therapy. In recent decades, ionizing radiation has been used more frequently, with the development of new diagnostic and therapeutic techniques. ${ }^{1}$ High quality images that allow quick and accurate diagnoses are considered indispensable nowadays in the clinical setting. The use of fluoroscopically-guided techniques in surgery has been increasing, and images in real time are now a vital tool for minimally invasive procedures. The International Commission on Radiological Protection states:

"Interventional radiology offers to medicine in all countries, no matter the stage of development, the opportunity to treat a greater range of pathologies, in more patients and at lesser cost. Interventional techniques reduce the need for expensive operating suites and extended hospital in-patient admissions. They also reduce most of the risks to the patient by the use of minimally invasive techniques

All authors declare no potential conflict of interest related to this article.

Study was Spine Surgery Division, Instituto de Ortopedia e Traumatologia, Hospital das Clínicas da Faculdade de Medicina da Universidade de São Paulo (IOT-HCFMUSP), São Paulo, Brazil.

Correspondence: Alexandre Fogaça Cristante. Rua Dr. Ovídio Pires de Matos, 333, São Paulo, SP, Brasil. 04018-001. aacristante@uol.com.br 
and through lesser requirements for general anesthesia". ${ }^{2}$ As a consequence of the increasing use of imaging in the surgical setting, exposure times, and the radiation doses involved with the use of fluoroscopy, have been increasing too. ${ }^{3}$

It is known that frequent exposure to ionizing radiation can cause serious health effects. Therefore, the risk to which individuals are exposed during tasks involving ionizing radiation must be carefully considered by professionals who work with radiology, radiotherapy and nuclear medicine services. ${ }^{3-5}$ In relation to the maximum amount of ionizing radiation to be used, there are principles that must be adhered to, in order to protect the patient. However, this dosage limitation does not apply to the exposure of medical staff to radiation. As a result, this exposure can be high in medical diagnosis, when compared with other medical procedures that use ionizing radiation. In fact, imaging exams are now the procedure that most contributes to radiation exposure. ${ }^{3}$ But there is a dose-response relationship between exposure to low doses of radiation and mortality, with significant increases in risk observed with doses of 100 to 200 mGy or higher. ${ }^{6}$ Ionizing radiation is used in a large number of procedures carried out in surgery centers. One such procedure is orthopedic surgery using the C-arm fluoroscope. The C-arm is essential in spinal surgeries, to guide the correct execution of the procedure. Despite the use of modern equipment with automatic control systems to limit exposure to radiation, which automatically adjust the voltage $(\mathrm{kV})$, electrical current and exposure time (mAs) to compensate for variations in thickness and density of the tissues being observed, the resulting radiation dose is significant for the patient, and also for the staff involved in the surgical procedures. ${ }^{3,4}$

Some studies have evaluated radiation doses in medical diagnoses and surgical centers, whether for patient, for occupationally exposed individuals (OIEs), or for the whole staff involved in the procedure. The majority of these studies either simulate surgical procedures or carry out the measurements during orthopedic or other procedures, in real time. ${ }^{7-9}$ However, there are no studies in Brazil focused on surgeons' exposure to ionizing radiation during surgical operations to the spine.

\section{MATERIALS AND METHODS}

This experimental study was conducted in the Spine Surgery Department of a large, public, university hospital in Brazil. The protocol was approved by the local ethics committee and all the participants (surgeons, technicians, nurses and auxiliary staff) involved signed informed consent forms for the radiation dose evaluations and inclusion in the study.

All the spinal surgeries performed in the department over a twelve-month period were evaluated. The same fluoroscopy equipment was used in all the procedures. Radiation film badge dosimeters were attached to fifteen standard sites, and kept in operation throughout the surgery:

1. Standard

2. Surgical center 1 - operating room wall

3. Surgical center 2 - opposite wall of the operating room

4. Below the operating room table

5. Surgeon 1 - attached to the lapel, over the lead apron

6. Surgeon 1 - attached to the lapel, under the lead apron

7. Surgeon 1 - wrist

8. Surgeon 2 - attached to the lapel, over the lead apron

9. Surgeon 2 - attached to the lapel, under the lead apron

10. Surgeon 2 - wrist

11. Instrumentator (scrub nurse) - attached to the lapel

12. Resident - attached to the lapel

13. C-arm operator - attached to the lapel, over the lead apron

14. C-arm operator - attached to the lapel, under the lead apron 15. Auxiliary - in the $c$ arm

The C-arm operator and the surgeons 1 (main surgeon) and 2 (auxiliary surgeon) used two badges attached to the lapel, one over the lead cover and another underneath it, and one attached to the wrist, under the surgical glove. Care was taken to leave the movements of the hands and arms free. Figure 1 shows how the film badge dosimeters were attached to the staff members, and Figure 2 shows the operating room table and the attachment of the dosimeter to the wall.

After each study period, the film badges were developed and analyzed in a radiology laboratory, and the following variables were recorded: date, procedure type and duration, voltage and electrical current of the $\mathrm{C}$-arm, and the distances between the main beam of the $\mathrm{C}$-arm and the professionals. These data were recorded on a filing card, as shown in Figure 3.

\section{RESULTS}

During the twelve-month period, 81 spinal surgeries were performed. The mean distances from the professionals to the radiation emission site during the procedures were almost the same in all procedures (Table 1). Table 2 shows data relating to the duration of surgery, and the voltage and electric current registered in the $\mathrm{C}$-arm, which varied according to the type of surgery performed.

The radiation doses recorded in the dosimeter devices over periods ranging from one to three months were grouped and analyzed in the laboratory. The results of each period are presented in Table 3. The total radiation doses varied from $0.16 \mathrm{mSv}$ (under the lead apron) to $2.29 \mathrm{mSv}$ (on the wrist of the main surgeon).

The last column of Table 3 shows the cumulative dose for the entire study period of about a year. The highest estimated dose was indicated for the badge dosimeters placed over the lead cover of surgeons 1 and 2, the professionals who are positioned closest to the primary beam and the patients. In such cases the dose to the professional is lower due to the protection offered by the lead apron, as indicated by the dosimeters positioned below this protective covering.

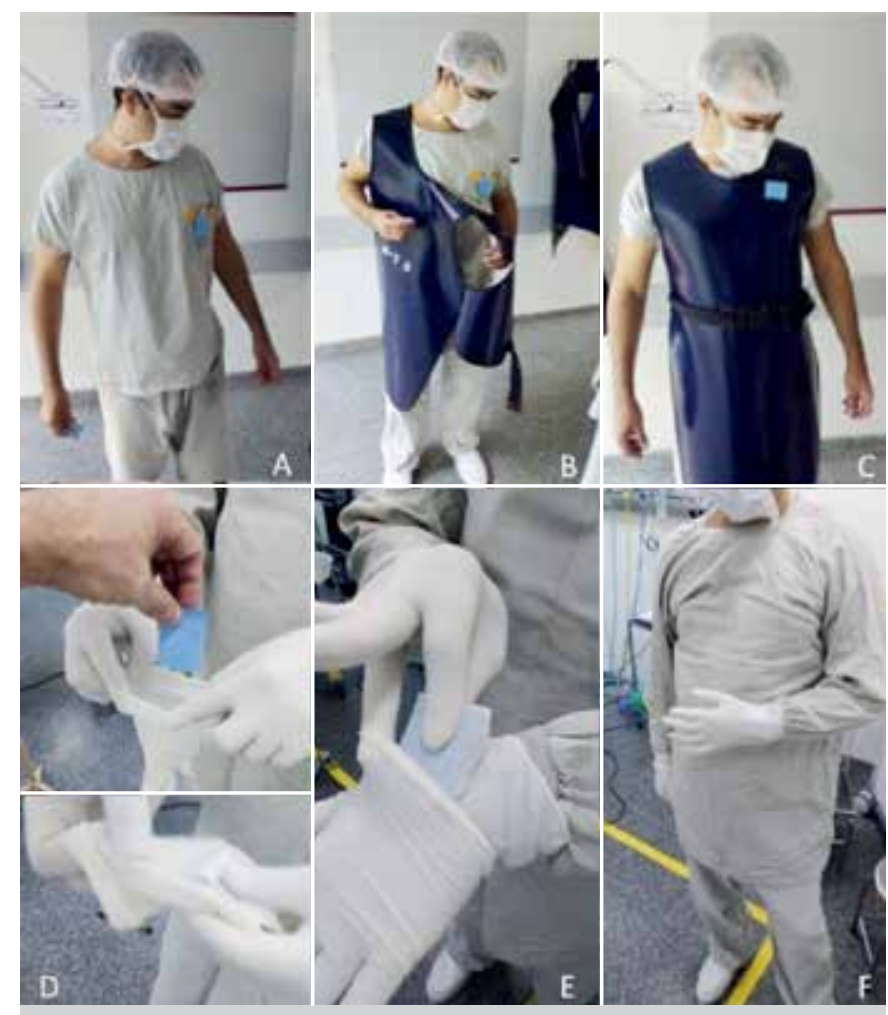

Figure 1. Attachment of film badge dosimeters to staff member body: A: lapel; B: lapel under lead apron; C: lapel over lead apron; D: inside the surgical glove; E; under sterile surgical glove; F: position on the wrist. 


\section{DISCUSSION AND CONCLUSIONS}

Exposure to radiation can be a cause of concern in spinal surgeries, which is a complex procedure usually involving six professionals in our service and lasting from one to six hours. Handling the fluoroscope potentially exposes surgeons to a radiation dose higher than the annual recommendation in orthopaedic procedures. ${ }^{10}$ A study on different types of surgery using fluoroscopy ${ }^{11}$ has shown that the total dose in orthopaedic procedures can reach $2.92 \mathrm{mGy} / \mathrm{m}^{2}$, with an effective dose of $58.4 \mathrm{mSv}$. As pointed out by Anupam Mahajan et al., orthopaedic surgeons are not considered as to be workers exposed to radiation, and radiation is usually seen as an additional secondary occupational hazard for them. ${ }^{12}$ Still, there are non-surgeon personnel in the operating room, and these should receive monitoring and protection. An experimental study using phantom anthropometric figures and simulating the spinal surgery setting showed that scatter radiation

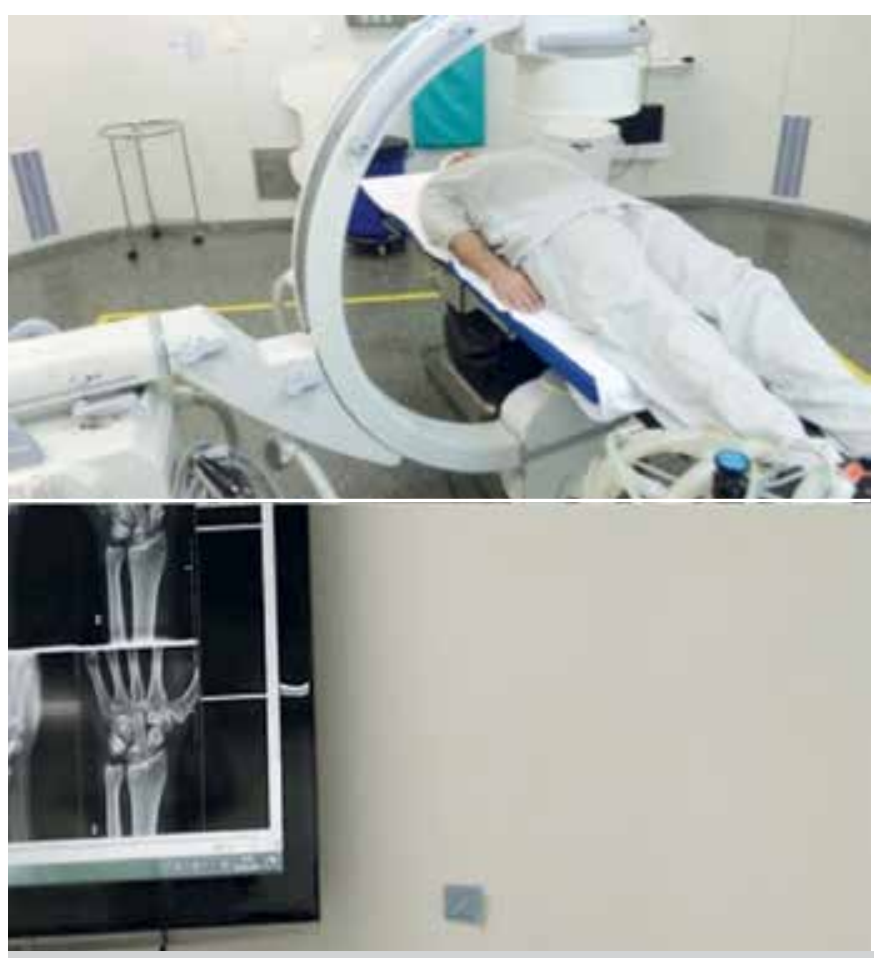

Figure 2. Operating room bed, under which a film badge dosimeter was placed and the operating room wall with a dosimeter badge attached.

\begin{tabular}{|c|c|c|c|c|c|c|c|c|c|}
\hline Date & $\begin{array}{c}\text { Procedure } \\
\text { type }\end{array}$ & $\begin{array}{c}\text { Duration } \\
(\mathrm{h}: \mathrm{min})\end{array}$ & $\begin{array}{c}\text { Voltage } \\
(\mathrm{kV})\end{array}$ & $\begin{array}{c}\text { El. Curr. } \\
(\mathrm{mA})\end{array}$ & \multicolumn{5}{|c|}{ Distance (cm) } \\
\cline { 6 - 8 } & & C1 & C2 & Instr. & Resid. & Oper. & Aux. \\
\hline
\end{tabular}

C1 = Surgeon 1; C2 = Surgeon 2; INSTR. = Instrumentator (scrub nurse); RESID. = Resident OPER. = C-arm operator; AUX. = Auxiliary.

Figure 3. Filling card used to record the data.

Table 1. Medium distance from the professionals to the radiation emission site during the procedures.

\begin{tabular}{l|c|c|c|c|c|c}
\hline Professional & Surgeon 1 & Surgeon 2 & Instrumentist & Resident & $\begin{array}{c}\text { C-arm } \\
\text { operator }\end{array}$ & Auxiliary \\
\hline Distance $(\mathrm{cm})$ & 40 & 40 & 60 & 100 & 100 & 120 \\
\hline
\end{tabular}

Table 2. Data collected during the procedures. Periods refer to the time taken for each batch of film badges to be taken to laboratory analysis.

\begin{tabular}{c|c|r}
\hline Procedure & Duration (h, min) & $\begin{array}{r}\text { Elect } \\
\text { tensio }\end{array}$ \\
\hline \multicolumn{3}{|c}{ Period A: two mont } \\
\hline Scoliosis & $1 \mathrm{~h} 10^{\prime}$ & \\
\hline Scoliosis & $0 \mathrm{~h} 50^{\prime}$ & \\
\hline Lumbar arthrodesis & $2 \mathrm{~h} 00^{\prime}$ & \\
\hline Scoliosis & $0 \mathrm{~h} 50^{\prime}$ & \\
\hline Lumbar arthrodesis & $1 \mathrm{~h} 10^{\prime}$ & \\
\hline Lumbar arthrodesis & $1 \mathrm{~h} 30^{\prime}$ & \\
\hline Lumbar arthrodesis & $2 \mathrm{~h} 10^{\prime}$ & \\
\hline
\end{tabular}

\begin{tabular}{c|c}
\hline Lumbar arthrodesis & Per \\
\hline Lumbar arthrodesis & \\
\hline Cervical arthrodesis & \\
\hline Scoliosis & \\
\hline Lumbar arthrodesis & \\
\hline
\end{tabular}

1 h20,

ovember, one month

Electric

Electric current (mA)

\begin{tabular}{c|c} 
& \\
\hline Infiltration & 2 \\
\hline Scoliosis & 3 \\
\hline Lumbar arthrodesis & 1 \\
\hline Lumbar arthrodesis & 3 \\
\hline Infiltration & 1 \\
\hline Lumbar scoliosis & 1
\end{tabular}

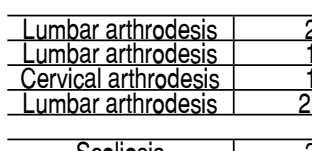

2h10

\begin{tabular}{l|l}
$10^{\prime}$ & 80 \\
\hline
\end{tabular}

Period C: one mon

\begin{tabular}{l|l}
\hline 75 & 0.9 \\
\hline 62 & 0.7 \\
\hline 85 & 0.9 \\
\hline 80 & 0.4 \\
\hline 90 & 0.8 \\
\hline 86 & 1.4 \\
\hline 88 & 1.3 \\
\hline
\end{tabular}

\begin{tabular}{l|l}
\hline 82 & 1,1 \\
\hline 86 & 1,3 \\
\hline 80 & 2,3 \\
\hline 80 & 1,1 \\
\hline 92 & 0,9
\end{tabular}

2 h05'

\begin{tabular}{c|c} 
2h05' & 65 \\
\hline 3h00' & 74 \\
\hline 1h30' & 10 \\
\hline $3 h 00^{\prime}$ & 80 \\
\hline 1h55' & 71 \\
1h45' & 77 \\
\hline \multicolumn{2}{|c|}{ Period D: one month }
\end{tabular}

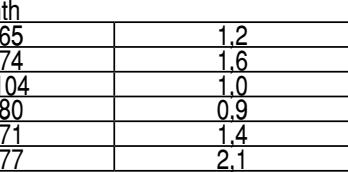

Cervical arthrodesis

\begin{tabular}{|c|r|}
\hline $2 h 40^{\prime}$ & 8 \\
\hline $1 h 50^{\prime}$ & 9 \\
\hline $1 h 20^{\prime}$ & 7 \\
\hline $2 h 510^{\prime}$ & 8 \\
\hline
\end{tabular}

Period E: one month

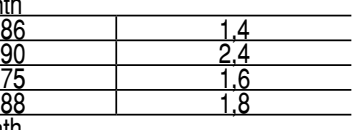

\begin{tabular}{c|c}
\hline Scoliosis & 3 \\
\hline Lumbar arthrodesis & 2 \\
\hline Lumbar arthrodesis & \\
\hline Lumbar arthrodesis & \\
\hline Lumbar arthrodesis & 3 \\
\hline Scoliosis & 3 \\
\hline Lumbar arthrodesis & 3 \\
\hline Scoliosis & 3 \\
\hline Scoliosis & 2 \\
\hline Scoliosis &
\end{tabular}

3 h10'

$\frac{2 h 10}{1 h 55}$

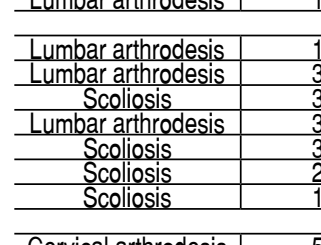

Period F: two mon

\begin{tabular}{c|c}
\hline Cervical arthrodesis & 5 \\
\hline Scoliosis & 6 \\
\hline Cervical arthrodesis & 1 \\
\hline Lumbar arthrodesis & 0 \\
\hline Arthrodesis & 1 \\
\hline Arthrodesis & 3 \\
\hline Scoliosis & 4 \\
\hline Cervical arthrodesis & 4 \\
\hline Scoliosis & 4 \\
\hline Lumbar arthrodesis & 3 \\
\hline Lumbar arthrodesis & 5 \\
\hline Lumbar arthrodesis & 2 \\
\hline Cervical arthrodesis & 3 \\
\hline Scoliosis & 4 \\
\hline Cervical arthrodesis & 2 \\
\hline Cervical arthrodesis & 1 \\
\hline Scoliosis & 2 \\
\hline Lumbar arthrodesis & 2 \\
\hline Lumbar arthrodesis & 3 \\
\hline Cervical arthrodesis & 5 \\
\hline Scoliosis & 3 \\
\hline Scoliosis & 4 \\
\hline Scoliosis & 4 \\
\hline Lumbar arthrodesis & 3 \\
\hline Cervical arthrodesis & 3 \\
\hline Lumbar arthrodesis & 3 \\
\hline Scoliosis & 4 \\
\hline . & 3 \\
\hline
\end{tabular}

\begin{tabular}{c|r}
\hline $1 \mathrm{~h} 30^{\prime}$ & 104 \\
\hline $3 \mathrm{~h} 00^{\prime}$ & 80 \\
\hline
\end{tabular}

\begin{tabular}{c|c}
\hline hoo' & 80 \\
\hline $3 \mathrm{~h}^{\prime}$ & 90 \\
\hline
\end{tabular}

$3 \mathrm{~h} 00^{\prime}$
3h30',
$2 \mathrm{~h} 00^{\prime}$

\begin{tabular}{l|l|l} 
& - & - \\
\hline
\end{tabular}

Period G: three months

\begin{tabular}{l|l}
\hline hoo' & 80 \\
\hline
\end{tabular}

\begin{tabular}{|c|c|}
\hline $6 h 40$, & 50 \\
\hline 1 hoo' & 80 \\
\hline
\end{tabular}

50 ,

h05'

\begin{tabular}{|c|c|}
\hline h $500^{\prime}$ & 104 \\
\hline $3 h 00^{\prime}$ & 10 \\
\hline h & 70 \\
\hline
\end{tabular}

\begin{tabular}{l|l}
\hline h00' & 104 \\
\hline
\end{tabular}

\begin{tabular}{c|c}
\hline 80 & 4.0 \\
50 & 1.3 \\
\hline 80 & 4.0 \\
\hline 104 & 0.7 \\
101 & 0,7 \\
70 & 2.0 \\
\hline 104 & 0.8 \\
80 & 1.6 \\
\hline 88 & 3,6 \\
\hline 82 & 3.2 \\
\hline 95 & 3.2 \\
\hline 90 & 3.6 \\
\hline 68 & 2.0 \\
88 & 3,6 \\
60 & 2.8 \\
\hline 60 & 2.0 \\
\hline 60 & 2.6 \\
\hline 65 & 3,0 \\
101 & 1.6 \\
\hline 71 & 3.0 \\
\hline 70 & 1.4 \\
\hline 105 & 2,4 \\
76 & 2.7 \\
\hline 109 & 7.1 \\
\hline 60 & 1.4 \\
\hline 70 & 3.2 \\
\hline 70 & 2,0 \\
\hline
\end{tabular}

\begin{tabular}{|c|c|c|c|}
\hline \multicolumn{4}{|c|}{ Period H: two months } \\
\hline Lumbar arthrodesis & $3 \mathrm{~h} 30^{\prime}$ & 48 & 2.4 \\
\hline Lumbar arthrodesis & $1 \mathrm{~h} 10^{\prime}$ & 90 & 2.4 \\
\hline Lumbar arthrodesis & $2 \mathrm{~h} 30^{\prime}$ & 62 & 3,4 \\
\hline Cervical arthrodesis & $4 h 00^{\prime}$ & 65 & 2.4 \\
\hline Cervical arthrodesis & $2 \mathrm{~h} 00^{\prime}$ & 70 & 1.6 \\
\hline Scoliosis & $2 \mathrm{~h} 30^{\prime}$ & 84 & 5.6 \\
\hline Lumbar arthrodesis & $2 \mathrm{~h} 20^{\prime}$ & 76 & 2,1 \\
\hline Cervical arthrodesis & $4 h 00^{\prime}$ & 64 & 1,8 \\
\hline Scoliosis & $3 \mathrm{~h} 00^{\prime}$ & 74 & 1.6 \\
\hline Lumbar arthrodesis & $1 \mathrm{~h} 30^{\prime}$ & 70 & 1.6 \\
\hline Lumbar arthrodesis & $3 \mathrm{~h} 30^{\prime}$ & 76 & 4.0 \\
\hline Lumbar arthrodesis & $4 \mathrm{~h}^{\circ} \mathrm{o}^{\prime}$ & 70 & 1,6 \\
\hline Decompression & $5 \mathrm{~h} 30^{\prime}$ & 76 & 2.4 \\
\hline Scoliosis & 5 h0o' & 74 & 1.6 \\
\hline Lumbar arthrodesis & $3 \mathrm{~h} 30^{\prime}$ & 76 & 2.4 \\
\hline Lumbar arthrodesis & $3 \mathrm{~h} 30^{\prime}$ & 82 & 3,0 \\
\hline Lumbar arthrodesis & 4h00' & 80 & 2.6 \\
\hline Scoliosis & $4 h 30^{\prime}$ & 80 & 2.0 \\
\hline Lumbar arthrodesis & $4 h 30^{\prime}$ & 80 & 2.6 \\
\hline Scoliosis & $6 h^{\prime} 00^{\prime}$ & 70 & 4,5 \\
\hline Cervical arthrodesis & $3 \mathrm{~h} 30^{\prime}$ & 81 & 4,0 \\
\hline Lumbar arthrodesis & $3 \mathrm{~h} 30^{\prime}$ & 70 & 4.0 \\
\hline Lumbar arthrodesis & $3 \mathrm{~h} 30^{\prime}$ & 82 & 3.0 \\
\hline
\end{tabular}

\begin{tabular}{l|l}
\hline 04 & 1,0 \\
\hline 80 & 0.9 \\
\hline 90 & 1,2 \\
\hline 72 & 2,0
\end{tabular}


Table 3. Results from radiation doses measurements per period (as indicated in Table 2); periods refer to the time taken for each batch of film badges to be taken to laboratory analysis.

\begin{tabular}{c|c|c|c|c|c|c|c|c|c}
\hline Professional & \multicolumn{7}{|c}{ Dose (mSv) per period } \\
\cline { 2 - 9 } & A & B & C & D & E & F & G & H & Total \\
\hline Standard & - & - & - & - & - & - & - & - & - \\
\hline $\begin{array}{c}\text { Surgical center 1- } \\
\text { operating room wall }\end{array}$ & 0.06 & 0.03 & - & - & - & - & 0.08 & - & 0.17 \\
\hline $\begin{array}{c}\text { Surgical center 2 - } \\
\text { operating room wall }\end{array}$ & - & - & 0.05 & 0.03 & - & - & 0.09 & 0.11 & 0.28 \\
\hline Below patient bed & - & - & - & 0.8 & 0.44 & - & 0.19 & - & 1.43 \\
\hline $\begin{array}{c}\text { Surgeon 1 - attached to the } \\
\text { lapel, over the lead apron }\end{array}$ & 0.15 & 0.13 & 0.05 & 0.08 & 0.03 & 0.05 & 0.41 & 0.29 & 1.19 \\
\hline $\begin{array}{c}\text { Surgeon 1 - attached to the } \\
\text { lapel, under the lead apron }\end{array}$ & 0.02 & - & 0.02 & - & - & - & 0.03 & 0.09 & 0.16 \\
\hline $\begin{array}{c}\text { Surgeon 2 - attached to the } \\
\text { lapel, over the lead apron }\end{array}$ & 0.02 & 0.07 & 0.05 & 0.21 & 0.06 & - & 0.29 & 0.12 & 0.82 \\
\hline $\begin{array}{c}\text { Surgeon 2 - attached to the } \\
\text { lapel, under the lead apron }\end{array}$ & 0.02 & - & 0.02 & 0.04 & - & - & 0.06 & 0.60 & 0.74 \\
\hline Instrumentator (scrub nurse) & - & - & - & - & 0.02 & - & 0.09 & 0.12 & 0.23 \\
\hline Resident & 0.06 & - & 0.02 & - & - & - & 0.09 & 0.10 & 0.27 \\
\hline $\begin{array}{c}\text { C-arm operator - attached to } \\
\text { the lapel, over the lead apron }\end{array}$ & 0.06 & - & 0.02 & 0.09 & - & - & 0.04 & 0.08 & 0.29 \\
\hline $\begin{array}{c}\text { C-arm operator - attached to } \\
\text { the lapel, under the lead apron }\end{array}$ & - & - & - & - & - & 0.03 & 0.04 & 0.09 & 0.16 \\
\hline Auxiliary & - & - & - & - & 0.07 & - & 0.13 & 0.04 & 0.24 \\
\hline Surgeon 1 - wrist & 1.43 & - & - & 0.81 & - & - & - & 0.05 & 2.29 \\
\hline Surgeon 2 - wrist & 0.10 & - & - & 0.35 & 0.07 & 0.02 & 0.02 & 0.03 & 0.59 \\
\hline Doses not mentioned are below the minimum detectable level (0.02 mSv) & & & \\
\hline
\end{tabular}

doses decreased as distance from the patient increased during the use of C-arm fluoroscopy. The study showed that the distance between the patient and the C-arm configuration, among other factors, could reduce radiation exposure during intraoperative use of the $\mathrm{C}$-arm. ${ }^{13}$ The position of the professional can also significantly alter the radiation exposure,$^{14}$ and the radiation dose may differ between the first assistant, the theatre nurse and the anesthesiologist, who might be exposed to higher radiation doses than the surgeon. ${ }^{15}$ In our study, we measured exposure to radiation in a real setting: the operating room during spinal surgeries, with real professionals at work, and we carefully evaluated the distances and the different measurement sites. It seems that in our setting, the exposure to radiation is below the legal requirements. The wrist badge dosimeters evidenced that the radiation dose in our surgeons' hands is also well below the maximum limit of 500 mSv per year. ${ }^{3,4,16,17}$

Analysis of the radiation dose registered by the film badge dosimeters, giving the estimated radiation to which staff are exposed, showed that there were no cases in which the values were above the level stipulated as total tolerated levels for an individual $(1,5 \mathrm{mSv})^{3,4}$ The doses to which all professionals were exposed in this study were slightly above the natural radiation levels in the environment, but far below the maximum dose allowed by local law $(20 \mathrm{mSv}$ as a five-year average). $3,4,16,17$

The results show that in this type of medical procedure, and under these study conditions, the resulting doses are low and the recommended limits were respected. Nevertheless, continual training of professionals is essential to ensure that medical staff and patients are protected against radiation.

AUTHORS' CONTRIBUTIONS: All authors made significant individual contributions to this manuscript. AFC $(0000-0002-7797-5274)^{\star}$, FB $(0000-0002-$ 9499-1321)*, AARS $(0000-0003-1698-131 X)^{*}$, and JCD (0000-0001-8999-8548)* contributed equally to the study design, data collection and interpretation, and manuscript writing and final revision. ${ }^{*} \mathrm{ORCID}$ (Open Researcher and Contributor ID).

\section{REFERENCES}

1. UNSCEAR (United Nations Scientific Committee on the Effects of Atomic Radiation). UNSCEAR 2008 Report to the General Assembly, with Scientific annexes. New York, United Nations 2010. [Assessed 2016, April 27.] Available at: http:// www.unscear.org/unscear/en/publications/2008_1.html.

2. International Commission on Radiological Protection. Avoidance of radiation injuries from medical interventional procedures. ICPR Publication 85. Ann ICRP 2000;30(2). [Accessed in 2016 (Feb 18).] Available form: http://www.icrp.org/ publication. asp?id=ICRP\%20Publication\%2085.

3. International Atomic Energy Agency. Regulatory control of radiation sources. Safety Standards No. GS-G-1.5. Vienna: International Atomic Energy Agency, 2004. [Accessed in 2016 (Feb 18).] Available from: http://www-pub.iaea.org/ MTCD/publications/PDF/Pub1192_Web.pdf.

4. Martin CJ. Radiation dosimetry for diagnostic medical exposures. Radiat Prot Dosimetry. 2008;128(4):389-412.

5. Gronchi CC. Exposição ocupacional às radiações ionizantes nos serviços de hemodinâmica. (Dissertação de Mestrado) São Paulo: Instituto de Pesquisas Energéticas e Nucleares; 2004

6. United Nations. Report of the United Nations Scientific Committee on the Effects of Atomic Radiation 2010. New York, United Nations 2011. [Assessed 2016, April 27] Available at: http://www.unscear.org/docs/reports/2010/UNSCEAR_2010_Report_M.pdf.

7. Leite ES, Uva AS, Serranheira F. Exposição a radiações ionizantes em cirurgia ortopédica num hospital público de Lisboa. Revista Portuguesa de Saúde Pública. 2006;6:55-66.

8. Oliveira SR, Azevedo ACP, Carvalho ACP. Elaboração de um programa de monitoração ocupacional em radiologia para o Hospital Universitário Clementino Fraga Filho. Radiol Bras. 2003;36(1):27-34

9. Giordano BD, Baumhauer JF, Morgan TL, Rechtine GR. Cervical spine imaging using standard C-arm fluoroscopy: patient and surgeon exposure to ionizing radiation. Spine (Phila Pa 1976). 2008;33(18):1970-6.
10. Comissão Nacional de Energia Nuclear. Diretrizes básicas de proteção radiológica (CNEN-NN-3.01). Rio de Janeiro: Comissão Nacional de Energia Nuclear; 2005. [Accessed in 2016 (Feb 18)] Available from: http://www.phymed.com.br/ fisica-medica/site/textos/nn_301.pdf.

11. Brasil. Ministério da Saúde. Secretaria de Vigilância Sanitária. Portaria 453 de 01 de junho de 1998. Diretrizes de Proteção Radiológica em Radiodiagnóstico Médico e Odontológico. Aprova o Regulamento Técnico que estabelece as diretrizes básicas de proteção radiológica em radiodiagnóstico médico e odontológico, dispõe sobre o uso dos raios-x diagnósticos em todo território nacional e dá outras providências. Brasília: Ministério da Saúde; 1998. [Accessed in 2016 (Feb 18)] Available from: http://www.phymed.com.br/fisica-medica/site/ textos/portaria453.PDF.

12. van der Merwe B. Radiation dose to surgeons in theatre. S Afr J Surg 2012;50(2):26-9.

13. Lee K, Lee KM, Park MS, Lee B, Kwon DG, Chung CY. Measurements of surgeons' exposure to ionizing radiation dose during intraoperative use of $\mathrm{C}$-arm fluoroscopy. Spine (Phila Pa 1976). 2012;37(14):1240-4.

14. Chang YJ, Kim AN, Oh IS, Woo NS, Kim HK, Kim JH. The Radiation Exposure of Radiographer Related to the Location in C-arm Fluoroscopy-guided Pain Interventions. Korean J Pain. 2014;27(2):162-7.

15. Müller MC, Strauss A, Pflugmacher R, Nähle CP, Pennekamp PH, Burger C, et al. [Evaluation of radiation exposure of personnel in an orthopaedic and trauma operation theatre using the new real-time dosimetry system "dose aware"]. Z Orthop Unfall. 2014;152(4):381-8.

16. Lee YS, Lee HK, Cho JH, Kim HG. Analysis of radiation risk to patients from intra-operative use of the mobile X-ray system (C-arm). J Res Med Sci. 2015;20(1):7-12.

17. Mahajan A, Samuel S, Saran AK, Mahajan MK, Mam MK. Occupational radiation exposure from $\mathrm{C}$ arm fluoroscopy during common orthopaedic surgical procedures and its prevention. J Clin Diagn Res. 2015;9(3):RC01-4. 